\title{
Hubungan Antara Self-Regulation Dengan Kecenderungan Adiksi Game Online Pada Mahasiswa Fakultas Teknologi Informasi Universitas Kristen Satya Wacana
}

\author{
Aprilia Tri Prasetiani, Margaretta Erna Setianingrum \\ Universitas Kristen Satya Wacana \\ apriliatriprasetiani@gmail.com, ernasetth@yahoo.com
}

\begin{abstract}
ABSTRAK
Penelitian ini bertujuan untuk mengetahui adanya hubungan negatif antara selfregulation dengan kecenderungan adiksi terhadap game online pada mahasiswa Fakultas Teknologi Informasi Universitas Kristen Satya Wacana. Teknik sampling yang digunakan purposive sampling. Jumlah sampel yang diambil ada 95 orang. Metode pengumpulan data pada variable adiksi game online berupa Game Addiction Scale yang diadopsi dari teori Griffths dan Davies (2004) yang menggambarkan adanya ketergantungan terhadap game online pada mahasiswa berdasarkan kriteria DSM IV dengan mengembangkan tujuh aspek diantaranya: Sailience, Tolerance, Mood Modification, Relapse, Withdrawal Symptoms, Conflict, dan Problems. Pada variable self-regulation menggunakan Self Regulation Quesionaire (SRQ) dari Brown, Millier, dan Lawendowski (1999). Hasil penelitian ini diperoleh nilai korelasi product moment rxy $=-0.545 ; p=0.00(p<0,05)$ yang berarti terdapat hubungan negatif dan signifikan antara self-regulation terhadap kecenderungan adiksi game online pada mahasiswa Fakultas Teknologi Informasi Universitas Kristen Satya Wacana.
\end{abstract}

Kata kunci: kecenderungan adiksi game online, self-regulation.

\begin{abstract}
This study aims to investigate the relationship between self-regulation with a tendency to addiction to online games in the satyawacanachristian university faculty student information technology. The number of samples were 95 people. Methods of data collection in the from of online gaming addiction variable Game Addiction Scale, which was adopted from the theory of Griffths and Davies (2004) which describes the dependence on online game on to student based on DSM IV criteria by developing seven aspects including: Sailience, Tolerance, Mood Modification, Relapse, Withdrawal Symptoms, Conflict, and Problems. In the variable self-regulation using Self Regulation Quesionaire (SRQ) from Brown, Millier, and Lawendowski (1999).The results of this study showed the value of the product moment correlations rxy=-0.545; $p=0.00$ ( $p<$ $0,05)$, which means there is a negative and significant relationships between selfregulation on the trend of online gaming addiction in satya wacana christian university information technology faculty students.
\end{abstract}

Keyword: the trend online gaming addiction, self regulation. 


\section{PENDAHULUAN}

Pada saat ini kemajuan teknologi berkembang sangat pesat, seperti halnya dengan media komunikasi dan media elektronik yang semakin hari mengalami perkembangan yang begitu sangatlah pesat. Salah satu yang berkembang pada saat ini adalah jaringan internet. Ketertarikan seseorang terhadap internet banyak bergantung kepada kepentingan, minat, dan kepribadian setiap individu seperti ketertarikan pada game online.

Tidak sedikit para mahasiswa yang ikut dalam bermain game online, bahkan rela menghabiskan uang jajannya untuk menikmati fasilitas permainan yang tersedia dalam game online, ini dikarenakan terdapat banyak jenis game dapat dimainkan yang memiliki akhir dan cara mencapainya artinya ada tujuan, dan hasil untuk mencapai keduanya. Game online ini juga dapat di mainkan melalui media smart phone (telfon genggam) dengan cara menggunakan paket data ataupun wifi yang ada disekitar kampus. Game online mempunyai perbedaan yang sangat besar dengan game yang lainnya yaitu pemain game tidak hanya dapat bermain dengan orang yang ada disebelahnya namun juga dapat bermain di lokasi lain, bahkan pemain yang ada dibelahan bumi lain (Young, 2007). Hal ini memungkinkan para pemain mendapatkan kesempatan sama-sama bermain dan beriteraksi serta membentuk komunitasnya sendiri dalam dunia maya.

Menurut Griffiths dan Davies (dalam Lemmens, 2009) yang menggambarkan adanya ketergantungan terhadap game online pada remaja berdasarkan kriteria DSM IV dengan mengembangkan tujuh aspek diantaranya: salience, mood modification, tolerance, withdarwl symptoms, conflict, relapse, dan problems. Fenomena dimana seseorang bermain game online secara berlebihan yang dapat menimbulkan efek buruk, Griffiths (2010). Selain itu kecanduan game online ini dapat mengakibatkan seseorang menjadi lebih agresif, sulit tidur, stress atau kecemasan bila tidak memainkan game tersebut, kesepian, dan berkurangnya hubungan sosial dengan lingkungan sekitar (Griffiths, 2012).

Yee (2002) menyatakan bahwa sebanyak $64,45 \%$ remaja laki-laki dan $47,85 \%$ remaja perempuan usia $12-22$ tahun yang mengalami kecanduan game online. Selain itu Imanuel (2009) menemukan bahwa dari 75 mahasiswa Universitas Indonesia yang mengalami kecanduan game online sebanyak 14 orang mewakili tingkat kecanduan tingkat tinggi, 12 orang dengan tingkat kecanduan rendah dan 49 orang memiliki tingkat kecanduan menengah. Penelitian ini menunjukkan mahasiswa yang bermain game online adalah pecandu menengah.

Menurut Young (1996), game online dapat membuat pecandunya jadi cuek, acuh tak acuh, kurang peduli terhadap hal-hal yang terjadi di lingkungan sekitar seperti kepada keluarga, teman dan orang-orang terdekat. Seseorang yang sudah kecanduan game online akan merasa dirinya tidak ingin melakukan hal lain selain bermain game tersebut, sehingga porsi waktu dalam hidupnya sebagian besar hanya untuk bermain game online (Grant, Kim, dan Potenza, 2003).

Menurut Santrock (2007) menyatakan bahwa masa peralihan dari remaja akhir 
ke dewasa awal berkisar usia 18-25 tahun, perubahan transisi dari remaja menuju dewasa yang sering terjadi yaitu transisi dari sekolah menengah ke perguruan tinggi dimana terjadi pengalaman positif dan negatif, bagi kebanyakan transisi melibatkan fokus pada perpindahan yang membuat stress dari sebagian kelompok siswa/mahasiswa. Pada kondisi ini perilaku menyimpang tersebut akan menjadi perilaku yang menggangu, melihat kondisi tersebut apabila didukung oleh lingkungan yang kurang kondusif dan sifat kepribadian yang kurang baik akan menjadi pemicu timbulnya berbagai penyimpangan perilaku dan perbuatan-perbuatan negatif yang melanggar aturan dan norma yang ada di masyarakat yang biasanya disebut dengan kenakalan remaja (Ekowarni, 1993).

Penelitian di American Medical Association menyatakan bahwa pada tahun 2007 terdapat $90 \%$ remaja amerika bermain game online dan $15 \%$ atau lebih dari 5 juta remaja mengalamikecanduan game online, sedangkan di Cina pada tahun 2007 terdapat $10 \%$ atau 30 juta remaja yang mengalami kecanduan game online (Young, 2009). Riset di Amerika Serikat menemukan bahwa beberapa organisasi mengalami dampak negatif sebagian akibat dari kecanduan akan game off-line (seperti Solitaire dan Tetris yang popular didekade 1980-an lalu), yang memang rata-rata banyak diinstal dalam komputer. Untuk saat ini game online tidak hanya dapat diinstal atau dimainkan di komputer saja, melainkan dapat di instal di handphone seperti, dota 1, dota 2, mobile lagend, pubg, hago, aof dan lain-lain yang banyak disukai banyak orang. Fenomena perilaku adiksi game online dikota Surakarta yang menunjukkan dampak negatif, pencurian oleh empat orang remaja yang nekat mencuri handphone di Boss Seluler, Karangasem, Laweyan, Surakarta karena kecanduan game online Point Blank (Wiratno, dalam Joglosemar, 2011). Koordinator Yayasan Sahabat Kapas, Dian Sasmita (Primantantyo, dalam Tempo.Com 2012) menyatakan bahwa dalam enam bulan pertama ditahun 2012 terdapat tujuh orang remaja yang melakukan pencurian demi bisa bermain game online.

Bahwa adiksi adalah suatu gangguan yang sifatnya berulang-ulang atau kronis, ditandai dengan perbuatan kompulsif yang dilakukan seseorang secara berulang-ulang untuk mendapatkan kepuasan pada aktivitas tertentu (Soetjipto, 2007). Hal ini membutuhkan pengaturan diri pada pecandu game online tersebut atau dengan kata lain regulasi diri (selfregulation) pada perilaku adiksi game online.

Regulasi diri (self-regulation) merupakan dasar dari proses sosialisasi karena berhubungan dengan seluruh doamain yang ada dalam perkembangan fisik, kognitif, sosial, dan emosional. Selain itu regulasi diri (self-regulation) juga merupakan kemampuan mental yang serta pengendalian emosi. Seluruh perkembangan kognitif, fisik, serta pengendalian emosi dan kemampuan sosialisasi yang baik, membawa seseorang untuk dapat mengatur dirinya dengan baik (Papalia, Olds dan Feldmen 2001). Menurut Brown dan Miller (dalam Papalia, Olds dan Feldmen, 2001) bahwa self-regulation atau regulasi diri sebagai kapasitas untuk merencanakan, mengarahkan, dan memonitor perilaku fleksibel untuk mengubah keadaan.

Menurut Schunk dan Zimmerman (dalam Susanto, 2006) regulasi diri (self-regulation) dapat dipahami sebagai penggunaan suatu 
proses yang mengaktivasi pemikiran, perilaku dan affet (perasaan) yang terus menerus dalam upaya untuk mencapai tujuan yang telah ditetapkan. Regulasi diri (self-regulation) meliputi selfgeneration dan pemantauan secara kognitif terhadap pikiran, perasaan dan perilaku dalam rangka mencapai suatu tujuan tanpa mengandalkan orang lain (Santrock, 2007).

Zimmerman (dalam Ormrod, 2003), menjelaskan jika seseorang disebut memiliki regulasi diri (self-regulation) jika pikiran dan perilakunya berada dibawah kendalinya sendiri, tidak dikendalikan oleh orang lain dan lingkungan. Dalam mencapai suatu tujuan yang diharapkan seseorang perlu mengetahui kemampuan fisik, kognitif, sosial, pengendalian emosi yang baik sehingga membawa seseorang kepada self-regulation yang baik. Menurut Brown dan Miller (dalam Neal dan Carey, 2005) terdapat tujuh aspek selfregulation yaitu: Receiving, Evaluating, Triggering, Searching, Formulating, Implementing, dan Assessing.

Baumeister dan Vosh (dalam McCullough dan Willoughby, 2009) dalam buletin psikologi yang diterbitkan APA (American Psychology Association) mendefinisikan regulasi diri dengan aktifitas bagaimana seseorang mengontrol dirinya atau tanggapannya untuk mengejar tujuan dan memenuhi standar. Self-regulation adalah kemampuan seseorang untuk menyelesaikan perilaku mereka agar sesuai dengan apa yang mereka ketahui sehingga dapat diterima oleh lingkungan sosialnya.

Menurut Pujiastuti (2015), menyatakan bahwa terdapat hubungan negatif yang signifikan antara regulasi diri (self-regulation) terhadap kecenderungan adiksi pada game online. Berdasarkan fenomena tersebut, peneliti tertarik untuk meneliti tentang hubungan self-regulation dengan kecenderungan adiksi game online pada mahasiswa Fakultas Teknologi Informasi Progdi S1 Teknik Informatika angkatan 2015 Universitas Kristen Satya Wacana.

Berdasarkan uraian latar belakang diatas maka rumusan masalah dalam penelitian ini adalah apakah ada hubungan negatif yang signifikan antara self-regulation dengan kecanduan adiksi game online pada mahasiswa Fakultas Teknologi Informasi Progdi S1 Teknik Informatika angkatan 2015 Universitas Kristen Satya Wacana.

\section{Kecenderungan Adiksi Game Online}

Game online adalah permainan dimana banyak orang yang dapat bermain pada waktu yang sama dengan melalui jaringan komunikasi online (internet). Fenomena dimana seseorang bermain game online secara berlebihan yang dapat menimbulkan efek buruk, Griffiths (2010). Selain itu kecanduan game online ini dapat mengakibatkan seseorang menjadi lebih agresif, sulit tidur, stress atau kecemasan bila tidak memainkan game tersebut, kesepian, dan berkurangnya hubungan sosial dengan lingkungan sekitar (Griffiths, 2012). Dengan demikian game online merupakan salah satu jenis kecanduan yang disebabkan oleh teknologi internet atau lebih dikenal dengan internet addective disorder (IAD). Internet dapat menyebabkan kecanduan, salah satunya dalah computer game addiction (berlebihan dalam bermain game).

Dari uraian diatas dapat disimpulkan pengertian adiksi game online adalah suatu keadaan seseorang terikat pada kebiasaan yang sangat kuat dan tidak bisa lepas untuk bermain game online. Seseorang pecandu game online dapat menghabiskan waktu untuk bermain sekitar 6 jam atau lebih dalam satu hari, jika tidak memiliki aktivitas yang dilakukan pecandu game online 
dalam satu hari, mereka terbiasa bermain game online lebih lama dan menghabiskan waktu hingga 20 jam dalam satu hari.

Menurut Griffiths dan Davies (dalam Lemmens, 2009) yang menggambarkan adanya ketergantungan terhadap game online pada remaja berdasarkan kriteria DSM IV dengan mengembangkan tujuh aspek diantaranya: salience atau berfikir tentang bermain game online sepanjang hari, tolerance atau waktu dalam bermain game online yang semakin meningkat, mood modification atau bermain game online untuk melarikan diri dari masalah, relapse atau kecenderungan untuk bermain game online kembali setelah lama tidak bermain, withdarwl symptoms atau merasa buruk jika tidak dapat bermain game online, conflict atau bertengkar dengan oranglain karena bermain game online secara berlebihan, dan problems atau mengabaikan kegiatan lainnya sehingga menyebabkan permasalahan.

Peneliti menyebutkan bahwa ada beberapa faktor yang mendorong seseorang untuk bermain game online. Faktor-faktor tersebut menurut Griffiths (2012) adalah: Faktor kepribadian; Pada faktor ini dikaitkan dengan seseorang yang cenderung memiliki kepribadian skizoid karena dirinya sering mengalami kesepian, kebosanan dan kurang berinteraksi dengan orang lain. Bahwa self-regulation menurut Brown dan Miller (dalam Papalia, Olds dan Feldmen, 2001) sebagai kapasitas untuk merencanakan, mengarahkan, dan memonitor perilaku fleksibel untuk mengubah keadaan, Faktor komorbiditas; merupakan faktor yang disebabkan karena individu tersebut mengalami gangguan seperti gangguan cemas umum, fobia, gangguan panik, depresi, dan berbagai gejala psikosomatis, dan Faktor biologis; yaitu yang telah mengalami kecanduan game online, ternyata ditemukan suatu substansi yang juga pada kecanduan lainnya, yaitu alel Taq1A1 dari reseptor dopamin dan val158Met dalam ketokolamin metiltransferase.

Menurut Brown dan Miller (dalam Papalia, Olds dan Feldmen, 2001) bahwa self-regulation atau regulasi diri sebagai kapasitas untuk merencanakan, mengarahkan, dan memonitor perilaku fleksibel untuk mengubah keadaan. Self-regulation adalah kemampuan seseorang untuk menyelesaikan perilaku mereka agar sesuai dengan apa yang mereka ketahui sehingga dapat diterima oleh lingkungan sosialnya.

Berdasarkan dari beberapa uraian diatas, dapat disimpulkan bahwa self-regulation (regulasi diri) adalah kemampuan dalam mengontrol, mengatur, merencanakan, mengarahkan, dan memonitor perilaku untuk mencapai tujuan tertentu dan melibatkan unsure fisik, kognitif, motivasi, emosional dan sosial.

Menurut Brown dan Miller (dalam Neal dan Carey, 2005) terdapat tujuh aspek self-regulation yaitu: receiving atau menerima informasi yang relevan, evaluating atau mengevalusi, triggering atau membuat suatu perubahan, searching atau mencarisolusi, formulating atau merancang suatu rencana, implementing atau menerapkan rencana, dan assessing atau mengukur efektivitas dari rencana yang telah dibuat.

Seseorang yang mengalami kecanduan game online akan mengalami beberapa gejala seperti, berfikir tentang bermain game online sepanjang hari (salience), bermain game online untuk melarikan diri dari masalah (mood modification), waktu dalam bermain game online yang semakin meningkat (tolerance), merasa buruk jika tidak dapat bermain game online (Withdarwl symptoms), 
bertengkar dengan oranglain karena bermain game online secara berlebihan (Conflict), kecenderungan untuk bermain game online kembali setelah lama tidak bermain (Relapse), mengabaikan kegiatan lainnya sehingga menyebabkan permasalahan (Problems). Tujuh kriteria kecanduan game online ini merupakan pengukuran untuk mengetahui kecanduan atau tidaknya seseorang pemain game online yang ditetapkan pemain yang mendapatkan empat dari tujuh kriteria merupakan indikasi pemain yang mengalami kecanduan game online (Lemmens, 2009).

Santrock

(2010), mengemukakan bahwa salah satu keterampilan yang penting dimiliki remaja adalah kemampuan meregulasi dan mengontrol emosi dan perilaku. Laki-laki biasanya memperlihatkan regulasi diri yang lebih rendah dibandingkan perempuan (Eisenberg, Spinrad, dan Smith, 2004).

Rendahnya regulasi diri pada diri individu menyebabkan permasalahan ecara kognitif, fisik, emosional maupun sosial. Salah satu permalahan yang ditimbulkan dari kecanduan game online ecara kognitif adalah menurunnya pretasi akademik (Yee, 2002). Permasalahan lainnya yang ditimbulkan akibat ketergantungan terhadap game online adalah masalah relasi sosialpada remaja. Menurut Hurlock (1999), remaja juga memiliki tugas untuk membentuk dan mempertahankan relasi social yang bertanggung jawab. Pemenuhan tugas perkembangan remaja tersebut memerlukan ketrampilan sosial. Young (1996), menemukan bahwa 53\% individu yang mengalami kecanduan internet mempunyai permasalahan dalam relasi sosialnya.

Penelitian Amstrong, Philips dan Salling (2000), menyimpulkan individu dengan ketrampilan sosial yang kurang atau kepercayaan diri yang rendah lebih mungkin untuk kecanduan terhadap internet sebagai bentuk kompensasi dari ketidak mampuannya tersebut. Kim, LaRose, dan Peng (2009) dalam penelitiannya menyatakan seseorang yang kesepian atau memiliki ketrampilan sosial yang rendah dapat membentuk perilaku kompulsif terhadap penggunaan internet dan menghasilkan dapak buruk bagi kehidupannya.

Berdasarkan uraian diatas, maka rumusan hipotesis yang diajukan dalam penelitan ini adalah terdapat hubungan yang negatif antara selfregulation dengan kecenderungan adiksi game online pada mahasiswa Fakultas Teknologi Informasi Progdi S1 Teknik Informatika angkatan 2015 Universitas Kristen Satya Wacana.

\section{METODE}

Penelitian ini mengunakan metode kuantitatif dengan teknik pengumpulan data berupa kuesioner atau angket. Penelitian ini menggunakan metode penelitian analisis kuantitatif dengan teknik pengambilan sempel yaitu nonprobality sampling dan menggunakan teknik sampling purposive. Subjek penelitian diambil dari populasi mahasiswa Fakultas Teknologi Informasi Progdi S1 Teknik Informatika angkatan 2015 Universitas Kristen Satya Wacana yang berjumlah 95 mahasiswa. Jenis penelitian ini menggunakan metode penelitian analisis kuantitatif dengan teknik pengambilan sempel yaitu nonprobality sampling dan menggunakan teknik sampling purposive. Sampling Purposive adalah teknik penentuan sampel dengan pertimbangan tertentu (Sugiyono, 2015). 
HASIL

\section{Analisis Deskriptif} Self-Regulation

Tabel 1.1 Kategorisasi Skor Variabel self-regulation

\begin{tabular}{|l|l|l|c|c|c|}
\hline No & Kategori & Interval & Frekuensi & Persentase & Mean \\
\hline 1 & Sangat rendah & $14<\mathrm{x}<25.5$ & 2 & $2.11 \%$ & \\
\hline 2 & Rendah & $25.5<\mathrm{x}<37$ & 2 & $2.11 \%$ & \\
\hline 3 & Tinggi & $37<\mathrm{x}<48.5$ & 53 & $55.78 \%$ & 48.55789 \\
\hline 4 & Sangat Tinggi & $48.5<\mathrm{x}<60$ & 38 & $40 \%$ & \\
\hline \multicolumn{2}{|r|}{ Jumlah } & 95 & $100 \%$ & \\
\hline
\end{tabular}

Pada tabel 1.1 kategori skor $40 \%$, pada kategori "Sangat variable self-regulation dari Rendah" didapat persentase sebesar sejumlah 95 subjek menunjukan tingkat penyebaran kategori dari sangat rendah hingga sangat tinggi. Dapat dilihat bahwa pada kategori "Tinggi" didapat persentase sebesar $55.78 \%$, pada kategori "Sangat Tinggi" didapat persentase sebesar

\section{Kecenderungan Adiksi Game Online}

Tabel 1.2 Kategorisasi Skor Variabel Kecenderungan Adiksi Game Online

\begin{tabular}{|c|c|c|c|c|c|}
\hline$\overline{\mathrm{No}}$ & Kategori & Interval & Frekuensi & Persentase & Mean \\
\hline 1 & Sangat rendah & $23<x<40.25$ & 23 & $24.22 \%$ & \\
\hline 2 & Rendah & $40.25<x<57.50$ & 57 & $60 \%$ & 49.90526 \\
\hline 3 & Tinggi & $57.50<x<74.75$ & 4 & $4.21 \%$ & \\
\hline 4 & Sangat Tinggi & $74.75<x<92$ & 11 & $11.58 \%$ & \\
\hline & \multicolumn{2}{|c|}{ Jumlah } & 95 & $100 \%$ & \\
\hline
\end{tabular}

Pada tabel 1.2 kategori skor variable kecenderungan adiksi game online dari sejumlah 95 subjek menunjukan tingkat penyebaran kategori dari sangat rendah hingga sangat tinggi. Dapat dilihat bahwa pada kategori "Rendah" didapat persentase sebesar $60 \%$, pada kategori "Sangat
$2.11 \%$, dan pada kategori "Rendah" didapat persentase $2.11 \%$. Dari tabel di atas juga dapat di lihat bahwa mean/rata-rata sebesar 48.55 yang berada pada kategori "Tinggi".

Rendah" didapat persentase sebesar $24.22 \%$, pada kategori "Sangat Tinggi" didapat persentase sebesar $11.58 \%$, dan pada kategori "Tinggi" didapat persentase $4.21 \%$. Dari tabel di atas juga dapat di lihat bahwa mean/rata-rata sebesar 49.90 yang berada pada kategori "Rendah". 


\section{Uji Asumsi}

\section{Uji Normalitas}

Tabel 2. Normalitas skala self-regulation dengan kecenderungan adiksi game online

\section{One-Sample Kolmogorov-Smirnov Test}

\begin{tabular}{|c|c|c|c|}
\hline & & SR & KAGL \\
\hline $\mathrm{N}$ & & 95 & 95 \\
\hline \multirow[t]{3}{*}{ Normal Parameters ${ }^{\mathrm{a}, \mathrm{b}}$} & Mean & 48.56 & 49.91 \\
\hline & Std. & & \\
\hline & Deviation & 7.618 & 14.597 \\
\hline \multicolumn{4}{|l|}{ Most Extreme } \\
\hline \multirow[t]{3}{*}{ Differences } & Absolute & .278 & .335 \\
\hline & Positive & .217 & .335 \\
\hline & Negative & -.278 & -.098 \\
\hline Test Statistic & & 2.711 & 3.268 \\
\hline $\begin{array}{l}\text { Asymp. Sig. (2- } \\
\text { tailed) }\end{array}$ & & $.000^{\mathrm{c}}$ & $.000^{\mathrm{c}}$ \\
\hline
\end{tabular}

Uji normalitas menggunakan uji Kolmogrov-Smirnov yang menunjukan variabel self-regulation memiliki nilai K-S-Z sebesar 2.711 dengan signifikansi $\quad 0.00 \quad(\mathrm{p}<0.05) . \quad$ Pada variable kecenderungan adiksi game online memiliki nilai K-S-Z sebesar
3.268 dengan signifikansi sebesar 0.00 $(\mathrm{p}<0.05)$. Dengan demikian dapat disimpulkan bahwa variable selfregulation dan kecenderungan adiski game online sama-sama berdistribusi normal.

\section{Uji Linearitas}

Tabel 3. Linearitas skala dimensiSelf-Regulation dan Kecenderungan Adiksi Game Online

\begin{tabular}{|c|c|c|c|c|c|c|c|}
\hline \multicolumn{8}{|c|}{ ANOVA Table } \\
\hline & & & $\begin{array}{l}\text { Sum of } \\
\text { Squares }\end{array}$ & $\mathrm{df}$ & $\begin{array}{l}\text { Mean } \\
\text { Square }\end{array}$ & $\mathrm{F}$ & Sig. \\
\hline \multirow{5}{*}{$\begin{array}{l}\text { SR * } \\
\text { KAGL }\end{array}$} & \multirow{3}{*}{$\begin{array}{l}\text { Between } \\
\text { Groups }\end{array}$} & (Combined) & 4902.293 & 29 & 169.045 & 19.865 & .000 \\
\hline & & Linearity & 1925.482 & 1 & 1925.482 & 226.266 & .000 \\
\hline & & $\begin{array}{l}\text { Deviation from } \\
\text { Linearity }\end{array}$ & 2976.811 & 28 & 106.315 & 12.493 & .095 \\
\hline & \multicolumn{2}{|c|}{ Within Groups } & 553.139 & 65 & 8.510 & & \\
\hline & \multicolumn{2}{|l|}{ Total } & 5455.432 & 94 & & & \\
\hline
\end{tabular}

Dari hasil uji linearitas table 3 diperoleh nilai $\mathrm{F}$ beda sebesar 12.493 dengan nilai sig $0.00 \quad(\mathrm{p}<0,05)$ yang menunjukan ada hubungan linear antara variabel self-regulation dengan kecenderungan adiksi game online. 
Uji Hipotesis

\section{Uji Korelasi}

Berdasarkan uji asumsi yang telah dilakukan, diketahui bahwa data tidak berdistribusi normal dan variabelvariabel penelitian linear. Sehingga uji

Tabel 4. Korelasi antaraSelf-Regulation dengan Kecenderungan Adiksi Game

Online correlation

\begin{tabular}{llrr} 
& & SR & KAGL \\
\hline \multirow{2}{*}{ SR } & $\begin{array}{l}\text { Correlation } \\
\text { Coefficient }\end{array}$ & -.545 & 1000 \\
\hline & $\begin{array}{l}\text { Sig. (1- } \\
\text { tailed) }\end{array}$ &. & .000 \\
\cline { 2 - 4 } & $\mathrm{N}$ & 95 & 95 \\
\hline KAGL & $\begin{array}{l}\text { Correlation } \\
\text { Coefficient }\end{array}$ & 1000 & -.545 \\
\hline
\end{tabular}

Sig. (1-

\begin{tabular}{lrr} 
tailed) &. & .000 \\
\hline $\mathrm{N}$ & 95 & 95
\end{tabular}

Dengan menggunakan uji korelasi Spearman's Rho diperboleh koefesien korelasi antara self-regulation dengan kecenderungan adiksi game online sebesar sebesar -0.545 dengan nilai signifikansi sebesar $0.00(\mathrm{p}<0.05)$ yang berarti ada hubungan antara selfregulation dengan kecenderungan adiksi game online.

Dalam penelitian ini penulis menuliskan hipotesis penelitian sebagai berikut ada hubungan negatif antara self-regulation dengan kecenderungan adiksi game online. Hasil penelitian yang diolah melalui uji korelasi Spearman's Rho menunjukkan koefisien korelasi $(\mathrm{r})=-0.545 ; \mathrm{p}=0.00$ $(\mathrm{p}<0,05)$ yang berarti ada hubungan yang signifikan antara self-regulation dengan kecenderungan adiksi game online pada mahasiswa Fakultas Teknologi Informasi Progdi S1 Teknik Informatika angkatan 2015 Universitas Kristen Satya Wacana. Hal ini berarti semakin tinggi self-regulation yang dimiliki mahasiswa maka semakin

$\begin{array}{lrr}\text { korelasi } & \text { dilakukan } & \text { dengan } \\ \text { menggunakan } & \text { statistik } & \text { non- } \\ \text { parametrik. Uji } \quad \text { korelasi } & \text { yang } \\ \text { digunakan dalam penelitian ini adalah } \\ \text { korelasi Spearman's Rho. }\end{array}$

rendah kecenderungan adiksi game online sebaliknya semakin rendah selfregulation yang dimiliki mahasiswa maka semakin tinggi kecenderungan adiksi game online. Dengan kata lain, variabel self-regulation memiliki peran terhadap munculnya variabel kecenderungan adiksi game online. Hasil penelitian tersebut didukung pula oleh analisis deskriptif pada tabel 1.1 dan tabel 1.2 menunjukkan bahwa variabel self-regulation berada pada kategori tinggi dan variabel kecenderungan adiksi game online berada pada kategori rendah terdapat pada mahasiswa Fakultas Teknologi Informasi Progdi S1 Teknik Informatika angkatan 2015 Universitas Kristen Satya Wacana.

Hubungan tersebut dapat terjadi karena sebagian mahasiswa Fakultas Teknologi Informasi Progdi S1 Teknik Informatika angkatan 2015 Universitas Kristen Satya Wacana dengan self-regulation yang tinggi ialah mahasiswa yang memiliki 
kecenerungan adiksi game online yang rendah seperti didalam merencanakan, mengarahkan, mengontrol diri, dan lainlain. Jika mahasiswa yang memiliki self regulation yang rendah maka kecenderungan adiksi game online yang tinggi seperti menjadi lebih agresif, stress, cemas, kesepian, berkurangnya hubungan sosial dan lain-lain. Pernyataan ini didukung oleh penelitian Pujiastuti (2015) yang menyatakan bahwa terdapat hubungan yang negatif antara self-regulation dengan kecenderungan adiksi game online.

Hubungan mahasiswa dengan selfregulation atau regulasi diri yang berarti perilaku dan pemikirannya berada didalam kendalinya sendiri bukan dikendalikan oleh lingkungannya. Dengan kata lain self-regulation atau regulasi diri berpengaruh bagi mahasiswa yang kecenderungan adiksi game online. Karena beberapa mahasiswa yang kecenderungan adiksi game online dapat mengendalikan diri mereka sendiri dan tidak dikendalikan oleh permainan game online yang mereka lakukan, mereka juga dapat mengatur waktu antara kuliah, bersosialisasi dengan lingkungan dan lain sebagainya. Dalam hasil penelitian ditemukan juga bahwa sumbangan efektif yang artinya pengaruh self- regulation dengan kecenderungan adiksi game online sebesar $37,6 \%$ dan $62,4 \%$ dipengaruhi oleh faktor lain.

Hal ini disebabkan karena pada sebagian mahasiswa Fakultas Teknologi Informasi Progdi S1 Teknik Informatika angkatan 2015 Universitas Kristen Satya Wacana merasa bahwa adanya self- regulation yang tinggi dapat mengurangi adanya adiksi bermain game online. Sementara pada sebagian mahasiswa lainnya tinggi atau rendahnya self-regulation yang mereka miliki tidak berpengaruh terhadap adiksi game online mereka.

\section{Kesimpulan}

Berdasarkan hasil penelitian ini terdapat hubungan negatif antara selfregulation terhadap kecenderungan adiksi game online, yang berarti semakin tinggi self-regulation maka semakin rendah kecenderungan adiksi game online yang dimiliki mahasiswa, sebaliknya semakin rendah selfregulationmaka semakin tinggi kecenderungan adiksi game online yang dimiliki mahasiswa. kepercayaan diri, tipe kepribadian dan sebagainya. 


\section{Daftar Pustaka}

1. Amstrong, Lynette, Philips, G. James \& L.L. Sailing. (2000). Potential Determinants of Behavior Internet Usange. International Journal of Human Computer Studies. Vol. 53. Page. 537-550.

2. Azwar, S. (2011). Metode Penelitian. Yogyakarta: Pustaka Belajar.

3. Eisenberg, N., Spinrad, T.L., \& Morris, A.S. (2004). Regulation, Resiliency, and Quality of Social Functioning. Self and Identity. 1, 121-128.

4. Ekowarni, E. (1993). Kenakalan Remaja : Suatu Tinjauan Psikologi. Bulletin Psikologi. Vol. 2 Hal 24-27.

5. Grant, J.E., Kim, S.W., \& Potenza, M.N.(2003). Advances in the pharmacological treatment of pathological gambling. Journal of Gambling Studies.19(1):85-109.

6. Griffiths, M.D. (2010). The role of context in online gaming excess and addiction: some case study evidence. International Journal of Mental Health andAddiction. 8:119-125.

7. Griffiths, M.D. (2012). Video gameaddiction : past, present and future. CurrentPsychiatry Reviews. 8:308-318.

8. Hurlock, E.B. (1999). Psikologi Perkembangan: Suatu Pendekatan Sepanjang Rentang Kehidupan. Alih bahasa: Istiwidayati \& Soedjarwo. Edisi Kelima. Jakarta: Erlangga.

9. Imanuel, N. (2009). Gambaran Profil Kepribadian yang Kecanduan Game Online dan yang Tidak Kecanduan Game Online. Depok: Fakultas Psikologi UI. (Online), (http://www.academia.edu.dampakgam eonline.html, diakses Februari 2019).

10. Kim, J., LaRose, R. \& Peng W. (2009). Loneliness as The cause and The Effect of Problematic Internet Use : The
Relationship Between Internet Use and Psychological Well Being. Cyber Psycology and Behavior. Vol. 12 No. 14 Page : 451-455.

11. Lemmens, J. S., Valkenburg, P. M., \&Peter, J. (2009). Development and validation of a game addiction scale for adolescents. Media Psychology, 12 (1), 77-95.

doi:

$10.1080 / 15213260802669458$.

12. McCullough, M.E., \& Willoughby, B.L.B. (2009). Religion, self-control, and self regulation: Associations, explanations, and implications. Psychological Bulletin.

13. Neal, J. \& Carey, B.K. (2005). A Follow-Up Psychometri Analysis of Self-Regulation Questionare. Psychology Journal : Psychology of Addictive Behaviour. 414-422.

14. Ormrod, J.E. (2003). Educational psychology $\left(4^{\text {th }}\right.$ ed.). New Jersey: Pearson Education.

15. Papalia, D.E., Olds, S.W., \& Feldmen, R.O. (2001). Human development. New York : McGraw-hill.

16. Primantantyo, Ukky. (2012). Kecanduan Game Online, Anak Bisa Kriminal.

http://www.tempo.co/read/news/2012/0 7/01/108414065/Kecanduan-GameOnline-Anak-Bisa-Kriminal. Diakses tanggal 25 april 2019.

17. Pujiastuti, F.D. (2015). Hubungan Regulasi Diri dengan Kecenderungan Adiksi Game Online. Skripsi. Fakultas Psikologi Universitas Kristen Satya Wacana. Salatiga.

18. Santrock, J.W. (2007). Life span development : perkembangan masa hidup (jilid 2). Jakarta. Erlangga.

19. Santrock, J.W. (2010). Adolescence : Perkembangan Remaja. Jakarta : Penerbit Erlangga. Alih bahasa oleh : Shinto B.A. dan S. Saragih. 
20. Sarwono, W.S. (2001). Psikologi Remaja. Jakarta: Grafindo Persada Hurlock, 1973.

21. Soetjipto. (2007). Berbagai Macam Adiksi dan Penatalaksanaanya. Anima: Indonesia Psychological Journal. Vol 23. No.1. p: 84-90.

22. Sugiyono. (2009). Metode Penelitian Kuantitatif, Kualitatifdan R\&D, Bandung : Alfabeta.

23. Sugiyono. (2015). Metode Penelitian Kuantitatif, Kualitatif dan $\mathrm{R}$ \& D. Bandung: Alfabeta.

24. Takwin, Bagus. (2008). Diri dan Pengelolaannya. Jurnal Psikologi Vol.14. Fakultas Psikologi Universitas Indonesia.

25. Wiratno, A. (2011). Kecanduan Game Online Empat Anak Ingusan Nekat Nyolong. http://harianjoglosemar.com/berita/kec anduan-game-online-empat-anakingusan-nyolong-61202.html. Diakses tanggal 25 april 2019.
26. Yee, N. (2002). Motivation of Play in Online Games. Cyberpsycho behavior. Vol.9 Page 772-775.

27. Young, K. S. (1996). Internet Addiction A New Clinical Phonomenon and its Consequences. Journal St. Bonaventura University Center for Online Addiction American Behavioral Scientist. Vol. 48 No. 4.

28. Young, K. S. (2007). Treatment outcomes with internet addicts. Clinical Director Center for Internet Addiction Recovery. Published in Cyber Psychology \& Behavior. 2007, 10 (5),671-679.

29. Young, K. S. (2009). Understanding online gaming addiction and treatment issues for adolescents. The American Journal of Family Therapy, 37, 355372. doi 10.1080/01926180902942191 (diakses April 2019). 